\title{
Sistem Penjadwalan Iklan Menggunakan Metode Priority Schedulling pada PT. Kidung Indah Selaras Suara (Radio Kiss FM) untuk Efektivitas dan Efisiensi Produksi Siaran
}

\author{
Allwin M. Simarmata ${ }^{1}$, Mawaddah Harahap ${ }^{2}$ \\ Address: Universitas Prima Indonesia , Program Studi Teknik Informatika, Indonesia \\ Email: allwinsimarmata@unprimdn.ac.id ${ }^{1}$, mawaddah@unprimdn.ac.id $^{2}$
}

\begin{abstract}
Abstrak
Pada umumnya, informasi melalui media ini dapat disalurkan dengan cepat karena menggunakan media audio yang mudah dipahami masyarakat. Selain itu, media ini tidak memerlukan biaya yang besar untuk mendapatkan informasinya, juga menjangkau seluruh lapisan masyarakat. Dikarenakan jumlah iklan yang harus disiarkan pada waktu yang terbatas cukup banyak, maka kelalaian dari salah satu bagian akan berakibat pada efisiensi waktu dan biaya, padahal waktu adalah komponen yang sangat berarti dalam memperoleh pendapatan. Selain itu, dalam manajemen untuk proses laporan, misalnya laporan tentang iklan yang disiarkan, harus dilakukan cross check antara bagian monitoring dan bagian produksi, ini merupakan proses yang memakan waktu lama jika dilakukan secara manual.

Berdasarkan fakta di atas, perlu dibuat software aplikasi untuk membuat bagian-bagian yang terkait dalam seluruh proses penyiaran iklan menjadi satu sistem yang terintegrasi, terutama yang berhubungan dengan penjadwalan iklan yang akan disiarkan pada suatu acara. Aplikasi dirancang dengan algoritma penjadwalan yang ada dalam bidang komputer khususnya sistem operasi. Proses penjadwalan iklan yang digunakan adalah dengan algoritma Priority Schedulling.
\end{abstract}

\section{Keywords - scheduling, algorithm, priority scheduling}

\section{Latar Belakang}

Perkembangan Teknologi Informasi saat ini berpengaruh pada banyaknya layanan penyedia informasi, salah satunya adalah media radio. Pada umumnya, informasi melalui media ini dapat disalurkan dengan cepat karena menggunakan media audio yang mudah dipahami masyarakat. Selain itu, media ini tidak memerlukan biaya yang besar untuk mendapatkan informasinya, juga menjangkau seluruh lapisan masyarakat. Dengan kata lain, media ini lebih efektif dan efisien.

Radio Kiss FM merupakan radio siaran swasta. Karena proses order, produksi, dan pelaporan dari iklan yang dilakukan oleh Kiss FM belum terintegrasi ke dalam satu sistem, dan proses produksi berupa penyiaran iklan belum terjadwal secara komputerisasi, maka dapat dikatakan proses produksi kurang efektif dan kurang efisien. Dikarenakan jumlah iklan yang harus disiarkan pada waktu yang terbatas cukup banyak, maka kelalaian dari salah satu bagian akan berakibat pada efisiensi waktu dan biaya, padahal waktu adalah komponen yang sangat berarti dalam memperoleh pendapatan. Selain itu, dalam manajemen untuk proses laporan, misalnya laporan tentang iklan yang disiarkan, harus dilakukan cross check antara bagian monitoring dan bagian produksi, ini merupakan proses yang memakan waktu lama jika dilakukan secara manual.

Berdasarkan fakta diatas, perlu dibuat software aplikasi untuk membuat bagian-bagian yang terkait dalam seluruh proses penyiaran iklan menjadi satu sistem yang terintegrasi, terutama yang berhubungan dengan penjadwalan iklan yang akan disiarkan pada suatu acara. Software aplikasi tersebut dibuat dengan suatu algoritma penjadwalan yang ada dalam bidang komputer khususnya sistem operasi. Algoritma penjadwalan ini, dimungkinkan sangat efektif untuk penjadwalan yang 
berhubungan dengan berharganya waktu, dalam arti semakin banyak iklan yang dijadwalkan maka semakin banyak keuntungan yang didapat. Tetapi ada kalanya tidak semua iklan yang dijadwalkan dapat tersiarkan semua karena suatu hal. Untuk itu, proses penjadwalan iklan yang digunakan adalah dengan algoritma Priority Schedulling. Algoritma ini, dipilih karena dengan melakukan pen- jadwalan penyiaran iklan berdasarkan pada prioritas dapat mengurangi kerugian biaya yang ditimbulkan karena kesalahan penjadwalan iklan. Hal ini, sesuai dengan keunggulan algoritma penjadwalan berprioritas dinamis yakni memenuhi kebijaksanaan yang ingin mencapai kondisi maksimum dari suatu kriteria yang ditetapkan.

\section{Metode}

\subsection{Pendjadwalan}

Penjadwalan (scheduling), didefinisikan sebagai proses pengalokasian sumber untuk memilih sekumpulan tugas dalam jangka waktu tertentu. Definisi ini dapat dijabarkan dalam arti yang berbeda, yaitu :

1. Penjadwalan merupakan sebuah fungsi pengambilan keputusan dalam menentukan jadwal yang paling tepat.

2. Penjadwalan merupakan teori yang berisi sekumpulan prinsip, model, teknik, dan konklusi logis dalam proses pengambilan keputusan.

Sistem penjadwalan adalah informasi berupa data dalam proses mengatur rencana kegiatan dengan pembagian waktu pelaksanaan. Priority Scheduling merupakan algoritma penjadwalan berprioritas. Tiap tiap proses dilengkapi dengan nomor prioritas (nilai integer terkecil biasanya merupakan prioritas terbesar). Pengerjaan mendahulukan proses yang memiliki prioritas terbesar. Jika beberapa proses memiliki prioritas yang sama, maka akan digunakan algoritma First come first served scheduling (FCFS).

Priority scheduling juga dapat dijalankan secara preemptive maupun non-preemptive. Pada preemptive, jika ada suatu proses yang baru datang memiliki prioritas yang lebih tinggi daripada proses yang sedang dijalankan, maka proses yang sedang berjalan tersebut dihentikan, lalu dialihkan untuk proses yang baru datang tersebut. Sementara itu, pada non-preemptive, proses yang baru datang tidak dapat mengganggu proses yang sedang berjalan, tetapi hanya diletakkan di depan queue.

Jika ada proses $P 1$ yang datang pada saat $P O$ sedang berjalan, maka akan dilihat prioritas $P 1$. Seandainya prioritas $P 1$ lebih besar dibanding dengan prioritas $P O$, maka pada non-preemptive, algoritma tetap akan menyelesaikan $P O$ sampai habis, dan meletakkan $P 1$ pada posisi head queue. Jika terdapat prioritas sama, maka proses yang pertama kali datang dikerjakan terlebih dahulu / First in first out (FIFO).

\subsection{Analisis Penjadwalan}

Untuk iklan komersial, prioritas ditentukan oleh klien, sedangkan untuk iklan layanan masyarakat dan iklan promo acara ditentukan oleh bagian Programming. Adapun ketentuan penomoran prioritas adalah sebagai berikut :

1. Penayangan komersial tayang setelah acara dan atau sebelum acara dimulai adalah prioritas utama atau ke satu.

2. Penayangan komersial tayang tepat sesuai jam tayang pada media order adalah prioritas ke dua.

3. Penayangan untuk iklan komersial yang tayang bebas (tidak memperhatikan waktu, hanya memperhatikan jumlah tayang) adalah prioritas ke tiga.

4. Penayangan iklan layanan masyarakat dan promo acara adalah prioritas ke empat.

Iklan yang didahulukan tayang yaitu iklan dengan nomor prioritas tertinggi. Jika terdapat iklan komersial dengan jenis produk yang sama, maka akan disisipkan iklan yang jenis produknya berbeda. Jika iklan memiliki nomor prioritas sama maka akan dijadwalkan terlebih dahulu iklan yang memiliki nomor order terkecil karena sesuai aturan bisnis yang sudah ditetapkan oleh radio Kiss FM. Jika waktu tayang iklan akan habis maka akan dijadwalkan iklan dengan nomor prioritas 4 , yaitu iklan layanan masyarakat atau promo program acara. Hal ini dimaksudkan agar tidak ada iklan yang tayang tidak tayang bersamaan dan tidak berbenturan dengan ketentuan penayangan komersial yang telah ditetapkan oleh radio Kiss FM.

\subsection{Algoritma Priority Scheduling}

Priority Scheduling merupakan algoritma penjadwalan yang mendahulukan proses yang memiliki prioritas tertinggi. Setiap proses memiliki prioritasnya masingmasing. Prioritas tersebut dapat ditentukan melalui beberapa karakteristik antara lain:

1. Time limit

2. Memory requirement

3. Akses file

4. Perbandingan antara I/O Burst dengan CPU Burst

5. Tingkat kepentingan proses

Priority scheduling juga dapat dijalankan secara preemptive maupun nonpreemptive. Pada preemptive, jika ada suatu proses yang baru datang memiliki prioritas yang lebih tinggi daripada proses yang sedang dijalankan, maka proses yang sedang berjalan tersebut dihentikan, lalu CPU dialihkan untuk proses yang baru datang tersebut.

Sementara itu, pada non-preemptive, proses yang baru datang tidak dapat menganggu proses yang sedang 
berjalan, tetapi hanya diletakkan di dalam queue. Berikut contoh analisis Algoritma Priority Scheduling : [4]

Tabel 2.1. Contoh Priority Scheduling

\begin{tabular}{|c|c|c|c|}
\hline Process & Duration & Priority & Arrival Time \\
\hline P1 & 6 & 4 & 0 \\
\hline P2 & 8 & 1 & 0 \\
\hline P3 & 7 & 3 & 0 \\
\hline P4 & 3 & 2 & 0 \\
\hline
\end{tabular}

Kelemahan pada priority scheduling adalah dapat terjadinya indefinite blocking (starvation). Yaitu proses dengan prioritas rendah berkemungkinan untuk tidak dieksekusi jika terdapat proses lain yang memiliki prioritas lebih tinggi darinya.

Solusi dari permasalahan ini adalah aging, yaitu meningkatkan prioritas dari setiap task yang menunggu dalam queue secara bertahap. Contoh: Setiap 10 menit, prioritas dari masing-masing task yang menunggu dalam queue dinaikkan satu tingkat. Maka, suatu task yang memiliki prioritas 127, setidaknya dalam 21 jam 20 menit, task tersebut akan memiliki prioritas 0 , yaitu prioritas yang tertinggi (semakin kecil angka menunjukkan bahwa prioritasnya semakin tinggi).

\subsection{Sistem Penjadwalan yang Berjalan}

Analisis sistem yang sedang berjalan adalah gambaran tentang sistem mengenai pengelolaan iklan yang sekarang sedang berjalan di radio Kiss FM dengan maksud untuk memahami terlebih dahulu masalah yang dihadapi oleh sistem, sehingga dapat diketahui hal-hal dan kebutuhan-kebutuhan apa saja yang belum terpenuhi oleh sistem yang sedang berjalan tersebut.

Analisis sistem mempunyai tujuan untuk dapat menentukan bentuk dari rancangan sistem yang akan diterapkan. sehingga dapat menentukan langkahlangkah perancangan yang akan dibuat yang sesuai dengan kebutuhan pemakai dan menghasilkan informasi yang cepat, tepat dan akurat.

1. Analisis Sistem

Analisis sistem adalah penguraian dari suatu sistem informasi yang utuh ke dalam bagian-bagian komponennya dengan maksud untuk mengidentifikasikan dan mengevaluasi permasalahan, kesempatan, hambatan yang terjadi dan kebutuhan yang diharapkan sehingga dapat diusulkan perbaikan.

a. Analisis Aturan Bisnis

Analisis aturan bisnis berisikan aturan-aturan yang berlaku pada sistem yang berjalan. Analisis aturan bisnis dibagi menjadi dua bagian yaitu analisis aturan bisnis berdasarkan fakta dan analisis aturan bisnis berdasarkan kebutuhan.

b. Analisis Aturan Bisnis Berdasarkan Fakta

Aturan bisnis yang terdapat pada kegiatan penjadwalan penayangan iklan di radio Kiss FM adalah sebagai berikut :

1. Pengisian NIP telah ditentukan oleh pihak radio Kiss FM dengan format yang dijelaskan pada analisis pengkodean.

2. Program acara minimal terdapat 2 segmen.

3. Tiap segmen berisi penayangan iklan.

4. Ketetapan waktu penayangan program acara, durasi tiap segmen, dan durasi penayangan iklan sesuai dengan yang ditentukan oleh radio Kiss FM.

5. Iklan dibedakan menjadi iklan komersial, iklan layanan masyarakat, dan iklan promo acara.

6. Iklan dijadwalkan berdasarkan ketentuan penayangan komersial yang ditetapkan oleh radio Kiss FM.

7. Contoh iklan layanan masyarakat diantaranya sosialisasi BKKBN, sosialisasi pemilu, dan pajak. Iklan layanan masyarakat dan iklan promo program acara dapat dipotong penyangannya untuk memenuhi waktu kosong pada slot penayangan iklan.

8. Iklan layanan masyarakat atau iklan promo program acara yang dipilih untuk memenuhi waktu kosong pada slot penayangan iklan ditentukan oleh Traffic.

c. Analisis Aturan Bisnis Berdasarkan Kebutuhan Analisis aturan bisnis berdasarkan kebutuhan pada sistem penjadwalan penayangan iklan di radio Kiss FM sesuai aturan bisnis berdasarkan fakta yang telah dijelaskan diatas dengan penambahan :

1. Pengaturan urutan penayangan iklan diasumsikan sebagai berikut :

a. Jika terdapat iklan yang tayang bersamaan, maka iklan yang pertama kali order akan dijadwalkan tayang terlebih dahulu.

b. Jika waktu tayang iklan pada sebuah segmen progam acara akan habis, maka akan dijadwalkan iklan promo acara atau iklan layanan masyarakat sampai waktu penayangan iklan habis.

2. Format file tayangan harian atau log proof yang diunduh dan file hasil penayangangan yang diunggah oleh Master Control Room (MCR) adalah .xls. 
3. Sebelum jadwal dibuat, data iklan dan data acara harus sudah dimasukan ke dalam sistem.

d. Analisis Penjadwalan

Analisis kegiatan penjadwalan bertujuan untuk menganalisis kegiatan penayangan di radio Kiss FM. Analisis kegiatan ini menggunakan Algoritma Priority Scheduling dengan menggunakan prioritas sebagai urutan penayangan iklan. Jika terdapat iklan yang memiliki durasi/burst time lebih kecil maka pada non-preemtive, algoritma akan diletakan pada posisi head-queue.

Untuk iklan komersial, prioritas ditentukan oleh klien, sedangkan untuk iklan layanan masyarakat dan iklan promo acara ditentukan oleh bagian Programming. Adapun ketentuan penomoran prioritas adalah sebagai berikut :

1. Penayangan komersial tayang setelah acara dan atau sebelum acara dimulai adalah prioritas utama atau ke satu.

2. Penayangan komersial tayang tepat sesuai jam tayang pada media order adalah prioritas ke dua.

3. Penayangan untuk iklan komersial yang tayang bebas (tidak memperhatikan waktu, hanya memperhatikan jumlah tayang) adalah prioritas ke tiga.

4. Penayangan iklan layanan masyarakat dan promo acara adalah prioritas ke empat.

\subsection{Perancangan Sistem}

Perancangan sistem pada Sistem Penjadwalan Iklan Terintegrasi Radio Kiss FM menggunakan Unified Modelling Language (UML). Untuk memvisualisasikan, menentukan, membangun, dan mendokumentasikan artifak dari sistem perangkat lunak. Use case diagram pada Sistem Penjadwalan Iklan Terintegrasi terdiri dari 7 (tujuh) use case dan 3 (tiga) aktor sistem seperti pada Gambar 3.1.

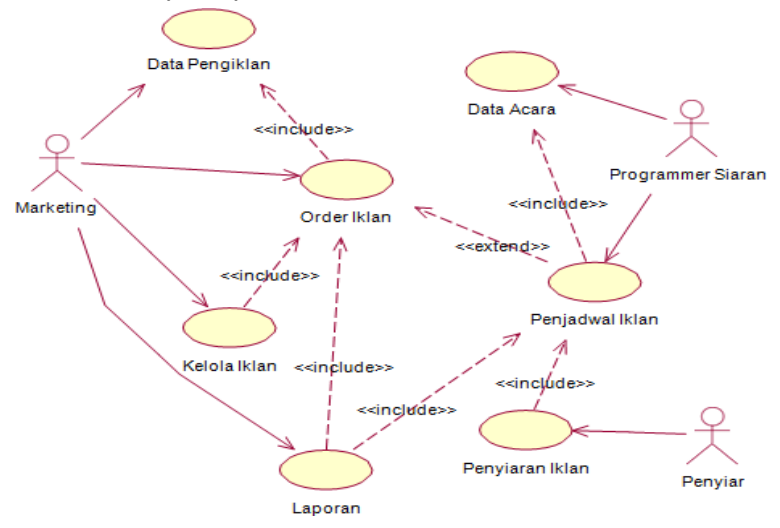

Gambar 3.1. Use Case Diagram Sistem Penjadwalan Iklan Terintegrasi
Gambar 3.1 menunjukkan use case diagram yang digunakan dalam membangun Sistem Penjadwalan Iklan Terintegrasi. Dalam use case diagram tersebut, dapat dilihat 3 (tiga) aktor pengguna sistem yang memiliki hak akses yang berbeda. Adapun hak akses dari setiap pengguna sistem dapat dilihat pada Tabel 3.6.

Tabel. 2.2. Daftar Hak Akses Pengguna Sistem

\begin{tabular}{ccc} 
No & Jenis Pengguna & Hak Akses \\
\hline 1 & Marketing & $\begin{array}{c}\text { 1. Mengelola data Pengiklanan } \\
\text { (klien) }\end{array}$ \\
& 2. Mengelola data iklan \\
& 3. Mengelola data order iklan \\
& 4iaran & 4. Serta melihat Laporan \\
\hline 2 & Pengelola data acara \\
& 2. Mengelola jadwal iklan & 1. Menyiarkan iklan \\
\hline
\end{tabular}

Langkah selanjutnya adalah merancang Class Diagram. Class diagram menggambarkan struktur sistem dari segi pendefinisian kelas-kelas yang akan dibuat untuk membangun sistem. Class diagram memiliki atribut dan metode atau operasi. Atribut merupakan variabel-variabel yang dimiliki oleh suatu kelas, sedangkan metode atau operasi merupakan fungsi-fungsi yang dimiliki oleh kelas. Berdasarkan dari use case diagram tersebut, maka class diagram yang digunakan untuk membangun Sistem Penjadwalan Iklan Terintegrasi adalah seperti pada Gambar 3.2.

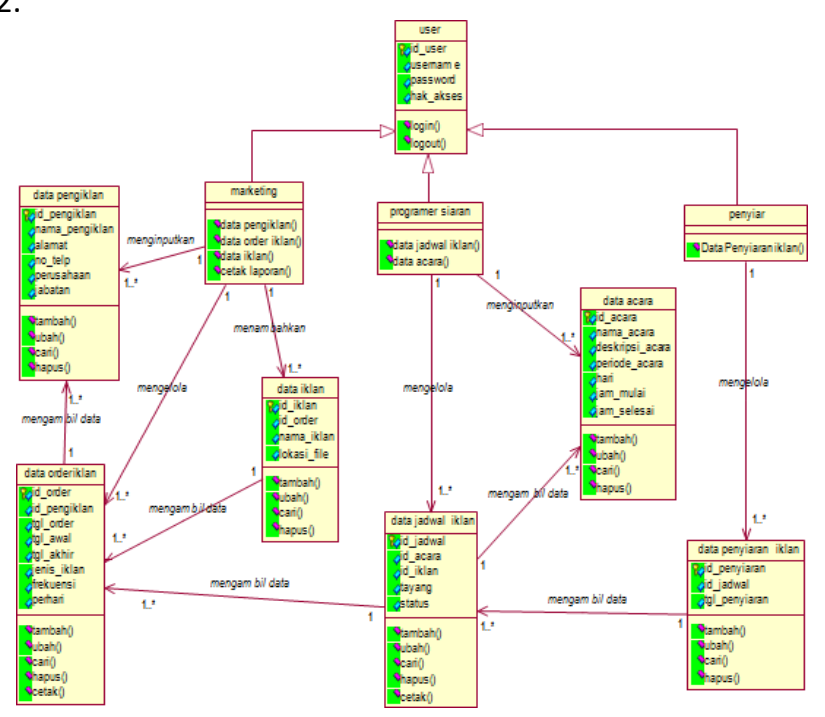

Gambar 2.3. Class Diagram Sistem Penjadwalan Iklan Terintegrasi

Program StudiTeknikInformatika 
Terlihat sebanyak 10 (sepuluh) class, yang terdiri dari 6 (enam) class yang digunakan sebagai obyek transaksi data dan 3 (tiga) buah class aktor sistem serta 1 (satu) class inheritance yaitu class induk dari 3 class aktor sistem. Database yang digunakan dalam Sistem Penjadwalan Iklan Terintegrasi pada Radio Suara Kudus adalah MySQL. Tabel yang digunakan dalam basis data penelitian ini adalah sebanyak 7 (tujuh) tabel seperti yang terlihat pada Gambar3.3.

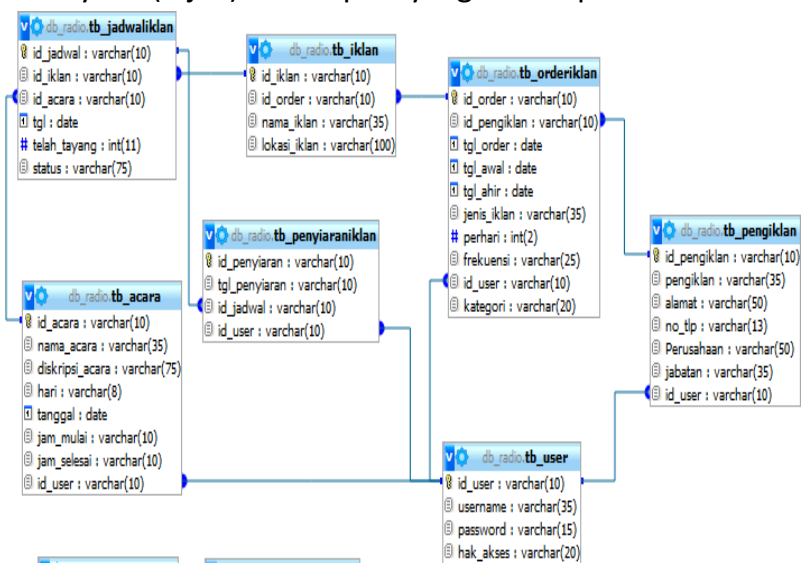

Gambar 2.4. Desain Relasi Tabel Pada Database

1. Prosedur Penerimaan Order Iklan

Prosedur penerimaan order iklan merupakan prosedur dimana klien memberikan order/berkas iklan ke perusahaan yang diterima langsung oleh divisi marketing.

a. client memberikan/mengirimkan surat order ke radio Kiss FM yang diterima langsung oleh divisi marketing. Order iklan berupa lembaran surat order yang berisi nama iklan, nama perusahaan pengiklan, periode penyiaran,nominal harga,frekuensi penyiaran iklan.

b. Divisi marketing melakukan evaluasi atau pengecekan terhadap order tersebut apakah nominal harga dan rinciannya telah sesuai dengan standar harga perusahaan, apabila belum maka divisi marketing akan melakukan negosiasi ulang sampai menemukan kesepakatan diantara kedua belah pihak dan mengirimkan kembali order iklan tersebut ke pihak klien untuk dilakukan revisi order.

c. Nominal harga order tersebut apabila telah sesuai dengan standar harga perusahaan maka order tersebut akan diserahkan ke divisi administrasi untuk dibuatkan surat persetujuan order.

d. Divisi administrasi menerima surat order iklan, kemudian membuatkan surat persetujuan order.

e. Staf administrasi memberikan surat persetujuan order kepada penanggung jawab untuk ditandatangani.

f. Setelah surat persetujuan order ditandatangani, surat persetujuan order tersebut diserahkan ke divisi marketing.

g. Divisi marketing menerima surat persetujuan order dari divisi administrasi yang kemudian dikirimkan/diserahkan ke klien sebagai bukti persetujuan penyiaran iklan di radio Kiss FM.

\section{Prosedur Penayangan Iklan}

Prosedur penayangan iklan merupakan prosedur dimana pihak administrasi menerima order iklan dari divisi marketing dan materi iklan dari pihak produksi dan melakukan penjadwalan iklan. Proses-prosesnya akan diuraikan sebagai berikut :

a. Divisi administrasi mengambil data-data iklan dari arsip order seperti nama iklan, nama perusahaan , periode, frekuensi penyiaran, harga, nomor order dan tanggal order ke dalam buku.

b. Berdasarkan data-data iklan tersebut, diambil data jam siar utuk membuat log iklan sebagai panduan penayangan iklan bagi penyiar.

c. Divisi produksi menyerahkan materi iklan yang siap siar ke administrasi.

d. Administrasi memasukan materi iklan tersebut ke folder iklan diruangan siaran.

e. Divisi administrasi menyerahkan log iklan ke ruang siaran (penyiar).

f. Penyiar menayangkan iklan tersebut sesuai jadwal yang telah disusun oleh divisi administasi dalam log iklan dan mengambil materi iklan dari folder yang telah ditentukan.

g. Penayangan iklan tersiar on air sesuai dengan jadwal.

h. Penyiar mengisi jam siar penanyangan iklan kedalam log iklan.

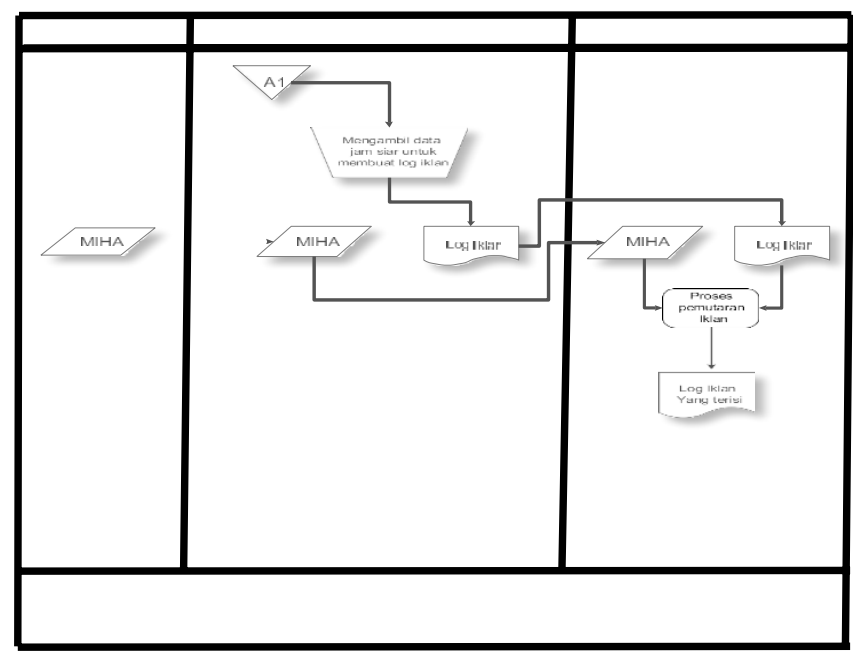

Gambar 2.5. Flow Map Penayangan Iklan

3. Prosedur Pelaporan Iklan 
Prosedur pelaporan iklan merupakan prosedur dimana pihak administrasi membuat laporan mengenai penyiaran iklan sesuai dengan periode yang telah disepakati dalam order iklan. Laporan yang dibuat antar lain bukti penyiaran iklan dan kwitansi penagihan iklan. Proses-prosesnya akan diuraikan sebagai berikut:

a. Divisi administrasi mengambil log iklan yang telah terisi jam siarnya oleh penyiar.

b. Log iklan akan dikumpulkan sesuai dengan periode penayangan iklan.

c. Untuk mempermudah pekerjaan maka dibuat rekap log iklan, selain itu administrasi juga mengecek data order iklan dari arsip order iklan untuk bahan pembuatan kwitansi.

d. Apabila iklan telah habis periode penayangannya, maka administrasi membuat laporan bukti siar dan juga kwitansi penagihan iklan

e. Bukti siar dan kwitansi yang telah dibuat diserahkan kepada penanggung jawab untuk ditandatangani.

$f$. Berkas kwitansi dan bukti siar tersebut diambil oleh administrasi kemudian diserahkan pada divisi marketing

g. Divisi marketing kemudian menyerahkan / mengirikan berkas kwitansi dan bukti siar tersebut kepada klien.

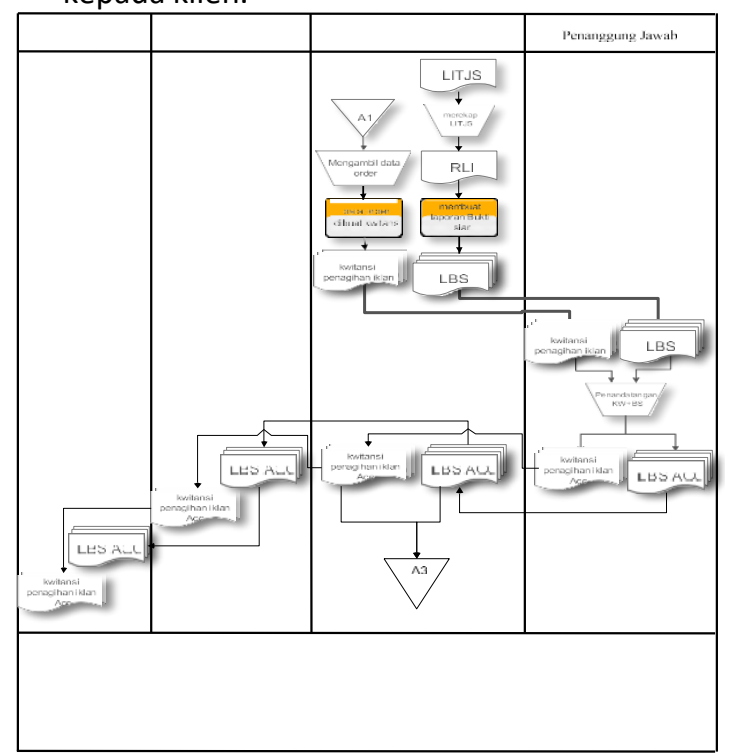

Gambar 2.6. Flow Map Pelaporan Iklan

\section{Perancangan Flowchart Prosedural Penjadwalan}

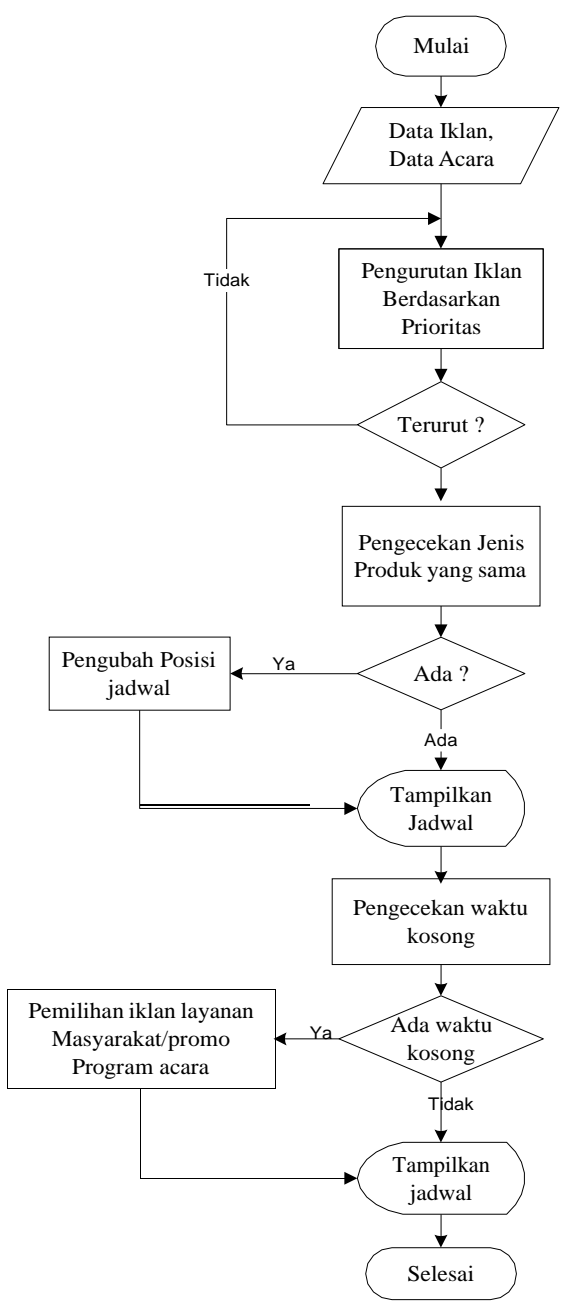

Gambar 2.7. Flowchart Prosedural Penjadwalan

5. Struktur Menu

Struktur menu dari aplikasi yang akan dibangun terdiri dari struktur menu untuk hak akses untuk pegawai di radio Kiss FM.

a. Struktur Menu Pengolahan Marketing

Berikut ini adalah struktur menu yang ada di divisi marketing, dapat terlihat dalam gambar 3.7. 


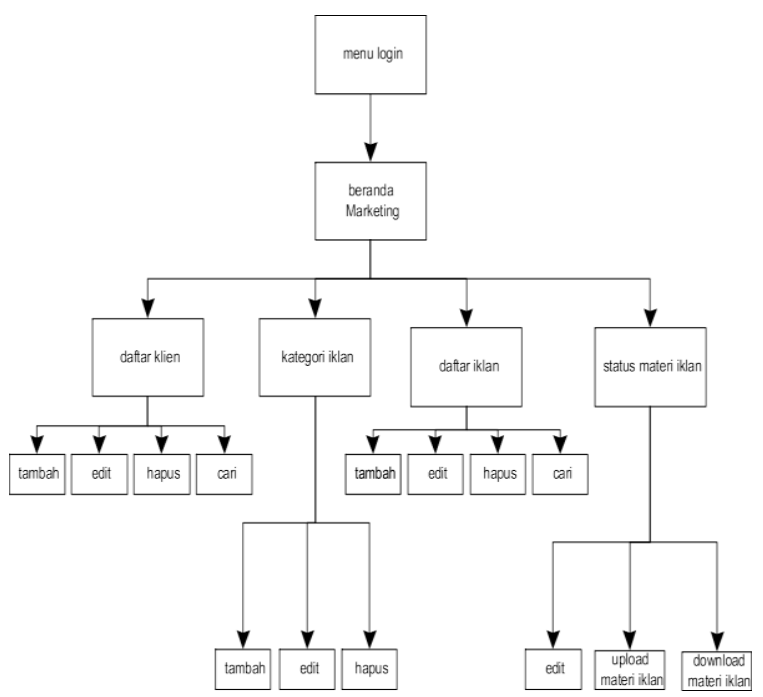

Gambar 2.8. Struktur Menu Pengolahan Data Iklan

b. Struktur Menu Divisi Produksi

Berikut ini adalah struktur menu di divisi marketing, dapat terlihat dalam gambar 3.8.
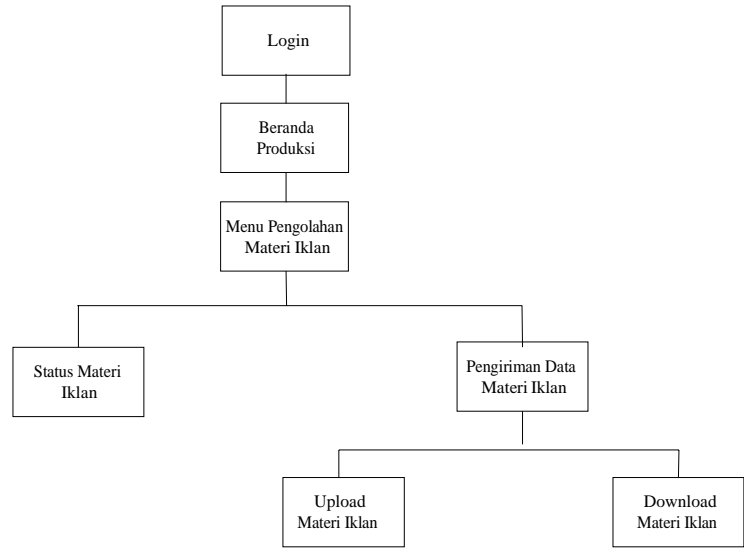

Gambar 2.9. Struktur Menu Pengolahan Materi Iklan Produksi

c. Struktur Menu Pengolahan Menyiarkan Iklan

Berikut ini adalah struktur menu Pengolahan menyiarkan iklan, dapat terlihat dalam gambar 2.9.

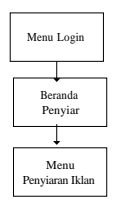

Gambar 2.9. Struktur Menu Pengolahan menyiarkan Iklan penyiar d. Struktur Menu Pengolahan Administrasi

Berikut ini adalah struktur menu yang ada di divisi administrasi, dapat terlihat dalam gambar 3.10 .

\subsection{Algoritma Priority Scheduling Penayangan Iklan}

Iklan yang didahulukan tayang yaitu iklan dengan nomor prioritas tertinggi. Jika terdapat iklan komersial dengan jenis produk yang sama, maka akan disisipkan iklan yang jenis produknya berbeda. Jika iklan memiliki nomor prioritas sama maka akan dijadwalkan terlebih dahulu iklan yang memiliki nomor order terkecil karena sesuai aturan bisnis yang sudah ditetapkan oleh radio Kiss FM. Jika waktu tayang iklan akan habis maka akan dijadwalkan iklan dengan nomor prioritas 4, yaitu iklan layanan masyarakat atau promo program acara. Hal ini dimaksudkan agar tidak ada iklan yang tayang tidak tayang bersamaan dan tidak berbenturan dengan ketentuan penayangan komersial yang telah ditetapkan oleh radio Kiss FM.

Contoh kasus, pada sebuah segmen program acara terdapat 5 iklan komersial yang akan dijadwalkan tayang. Durasi penayangan iklan pada segmen program acara tersebut yaitu 3 menit. Tabel 3.3 menjelaskan iklan yang akan dijadwalkan tayang.

Tabel Iklan yang dijadwalkan

\begin{tabular}{|c|c|c|c|c|c|}
\hline $\begin{array}{c}\text { No } \\
\text { Orde } \\
\mathbf{r}\end{array}$ & Brand & $\begin{array}{c}\text { Jenis } \\
\text { Produk }\end{array}$ & $\begin{array}{c}\text { Jenis } \\
\text { Iklan }\end{array}$ & Durasi & Prioritas \\
\hline 06 & Telkomsel & Provider & Kormesial & $\begin{array}{c}30 \\
\text { detik }\end{array}$ & 1 \\
\hline 09 & Icih Magz & Majalah & Kormesial & $\begin{array}{c}23 \\
\text { detik }\end{array}$ & 2 \\
\hline 11 & Indosat & Provider & Kormesial & $\begin{array}{c}60 \\
\text { detik }\end{array}$ & 4 \\
\hline 18 & $\begin{array}{c}\text { CV. Hanung } \\
\text { Perkasa }\end{array}$ & Promo & Kormesial & $\begin{array}{c}50 \\
\text { detik }\end{array}$ & 3 \\
\hline
\end{tabular}

Pada Tabel 3.3 tampak bahwa iklan dengan nomor order 06, dengan nama telkomsel jenis produk provider jenis iklan kormesial durasi 30 detik, dan memiliki prioritas ke dua yaitu penayangan tepat sesuai dengan jam tayang pada media order.

Langkah pertama, urutkan iklan berdasarkan nomor prioritas diawali dengan nomor prioritas tertinggi dan seterusnya, seperti terlihat pada Tabel 3.4 Pengurutan juga dilihat berdasarkan nomor order, dimulai dari nomor order terkecil.

Gantt chart :

Telkomsel Icih Magz CV.

\begin{tabular}{r|r|r|r|} 
Hanung Perkasa & Indosat \\
\hline P1 & P2 & P3 & P4 \\
\hline
\end{tabular}

Program StudiTeknikInformatika 


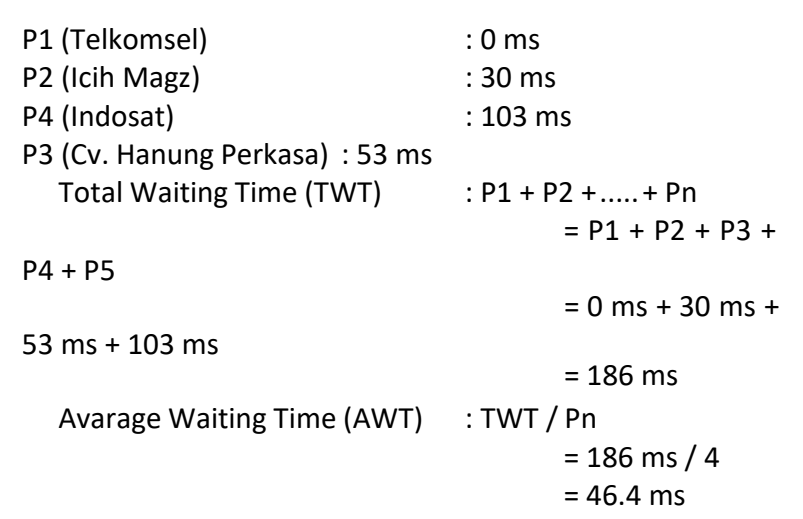

Tabel Pengurutan Nomor Prioritas

\begin{tabular}{|c|c|c|c|c|c|}
\hline $\begin{array}{c}\text { No } \\
\text { Order }\end{array}$ & Brand & $\begin{array}{c}\text { Jenis } \\
\text { Produk }\end{array}$ & Jenis Iklan & Durasi & Prioritas \\
\hline 06 & Telkomsel & Provider & Kormesial & $\begin{array}{c}30 \\
\text { detik }\end{array}$ & 1 \\
\hline 09 & Icih Magz & Majalah & Kormesial & $\begin{array}{c}23 \\
\text { detik }\end{array}$ & 2 \\
\hline 18 & $\begin{array}{c}\text { CV. } \\
\text { Hanung } \\
\text { Perkasa }\end{array}$ & Promo & Kormesial & $\begin{array}{c}50 \\
\text { detik }\end{array}$ & 3 \\
\hline 11 & Indosat & Provider & Kormesial & $\begin{array}{c}60 \\
\text { detik }\end{array}$ & 4 \\
\hline
\end{tabular}

Gantt chart :

Telkomsel

Icih

Indosat

Hanung Perkasa

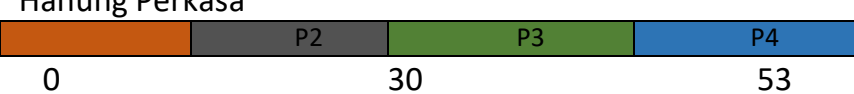

Langkah kedua, jika terdapat jenis produk yang sama maka disisipkan dengan iklan yang memiliki jenis produk yang berbeda. Pemilihan iklan untuk disisipkan dipilih dari nomor order terkecil. Pada Tabel 3.4 tampak iklan dengan nomor order 31, nama brand Suwanda, jenis produk Pileg yang terpilih untuk disisipkan diantara jenis produk yang sama yaitu jenis produk provider.

Tabel Pengecekan Jenis Produk

\begin{tabular}{|c|c|c|c|c|c|}
\hline $\begin{array}{c}\text { No } \\
\text { Order }\end{array}$ & Brand & $\begin{array}{c}\text { Jenis } \\
\text { Produk }\end{array}$ & Jenis Iklan & Durasi & Prioritas \\
\hline 09 & Icih Magz & Majalah & Kormesial & 23 detik & 2 \\
\hline 06 & Telkomsel & Provider & Kormesial & 30 detik & 1 \\
\hline 18 & $\begin{array}{c}\text { CV. } \\
\text { Hanung } \\
\text { Perkasa }\end{array}$ & Promo & Kormesial & 50 detik & 3 \\
\hline 11 & Indosat & Provider & Kormesial & 60 detik & 4 \\
\hline
\end{tabular}

Langkah ketiga yaitu menghitung total waktu penayangan iklan dengan cara menjumlahkan durasi dari tiap iklan. Pada Tabel durasi iklan Icih Magz 23 detik

ditambah durasi iklan Telkomsel 30 detik sehingga pada real time dapat dilihat total waktu setelah ditambah menjadi 00:53. Berikut perhitungannya

Gantt chart :

Icih Magz

Hanung Perkasa

Telkomsel

CV.

\begin{tabular}{|c|c|c|c|}
\hline P1 & P2 & P3 & P4 \\
\hline 0 & 30 & & 53 \\
\hline
\end{tabular}

P2 (Telkomsel)
P1 (Icih Magz)
P4 (Indosat)
P3 (Cv. Hanung Perkasa) : $103 \mathrm{~ms}$
$\quad$ Total Waiting Time (TWT)
+ P5
$103 \mathrm{~ms}+163 \mathrm{~ms}$

Avarage Waiting Time (AWT) $:$ TWT / P : $53 \mathrm{~ms}$ : $30 \mathrm{~ms}$ : $163 \mathrm{~ms}$ $: P 1+P 2+\ldots .+P n$ $=P 1+P 2+P 3+P 4$ $=30 \mathrm{~ms}+53 \mathrm{~ms}+$ $=349 \mathrm{~ms}$

$=186 \mathrm{~ms} / 4$ $=87.25 \mathrm{~ms}$

Tabel Perhitungan Total Durasi

\begin{tabular}{|c|c|c|c|c|c|c|}
\hline $\begin{array}{c}\text { No } \\
\text { Order }\end{array}$ & Brand & $\begin{array}{c}\text { Jenis } \\
\text { Produk }\end{array}$ & $\begin{array}{l}\text { Jenis } \\
\text { Iklan }\end{array}$ & Durasi & $\begin{array}{c}\text { Priorita } \\
\mathbf{s}\end{array}$ & $\begin{array}{l}\text { Real } \\
\text { Time }\end{array}$ \\
\hline 09 & Icih Magz & Majalah & Kormesial & $\begin{array}{c}23 \\
\text { detik }\end{array}$ & 2 & $00: 25$ \\
\hline 06 & Telkomsel & Provider & Kormesial & $\begin{array}{c}30 \\
\text { detik }\end{array}$ & 1 & $00: 45$ \\
\hline 18 & $\begin{array}{l}\text { CV. } \\
\text { Hanung } \\
\text { Perkasa }\end{array}$ & $\begin{array}{l}103 \\
\text { Promo }\end{array}$ & $\begin{array}{r}16 \\
\text { Kormesial }\end{array}$ & $\begin{array}{c}50 \\
\text { detik }\end{array}$ & 3 & $01: 32$ \\
\hline 11 & Indosat & Provider & Kormesial & $\begin{array}{c}60 \\
\text { detik }\end{array}$ & 4 & 01:52 \\
\hline 18 & pepsodent & Promo & Kormesial & $\begin{array}{c}35 \\
\text { detik }\end{array}$ & 5 & 02:27 \\
\hline
\end{tabular}

Total waktu penayangan iklan komersial pada Tabel 3.6 adalah 2 menit 27 detik, maka sisa waktu penayangan iklan yaitu 33 detik. Sisa waktu penayangan iklan akan diisi dengan iklan layanan masyarakat atau promo program acara yang dapat dilihat pada Tabel 3.7 sehingga waktu penayangan iklan sebanyak 3 menit dapat terpenuhi.

Gantt chart :

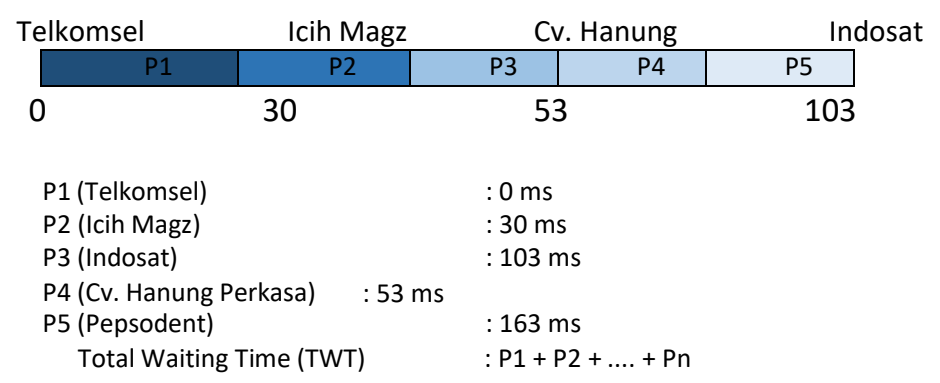

Program StudiTeknikInformatika 


$\begin{aligned} & =\mathrm{P} 1+\mathrm{P} 2+\mathrm{P} 3+\mathrm{P} 4 \\ & \\ 53 \mathrm{~ms}+103 \mathrm{~ms}+163 \mathrm{~ms} & =0 \mathrm{~ms}+30 \mathrm{~ms}+ \\ & =349 \mathrm{~ms} \\ \text { Avarage Waiting Time (AWT) } \quad: \text { TWT } / \mathrm{Pn} & =349 \mathrm{~ms} / 5 \\ & =69.8 \mathrm{~ms}\end{aligned}$

Tabel 3.7. Penambahan Iklan
Pembuatan jadwal yang diterapkan akan menghasilkan total nilai keuntungan potensial yang didapat dari total seluruh penayanga iklan yang ditayangkan tepat waktu dikurangi dengan nilai kerugianiklan tidak ditayangkan yang diakibatkan melebihi batas produksi penayangan yang telah ditentukan.

Tabel Parameter Produksi Penayangan Iklan

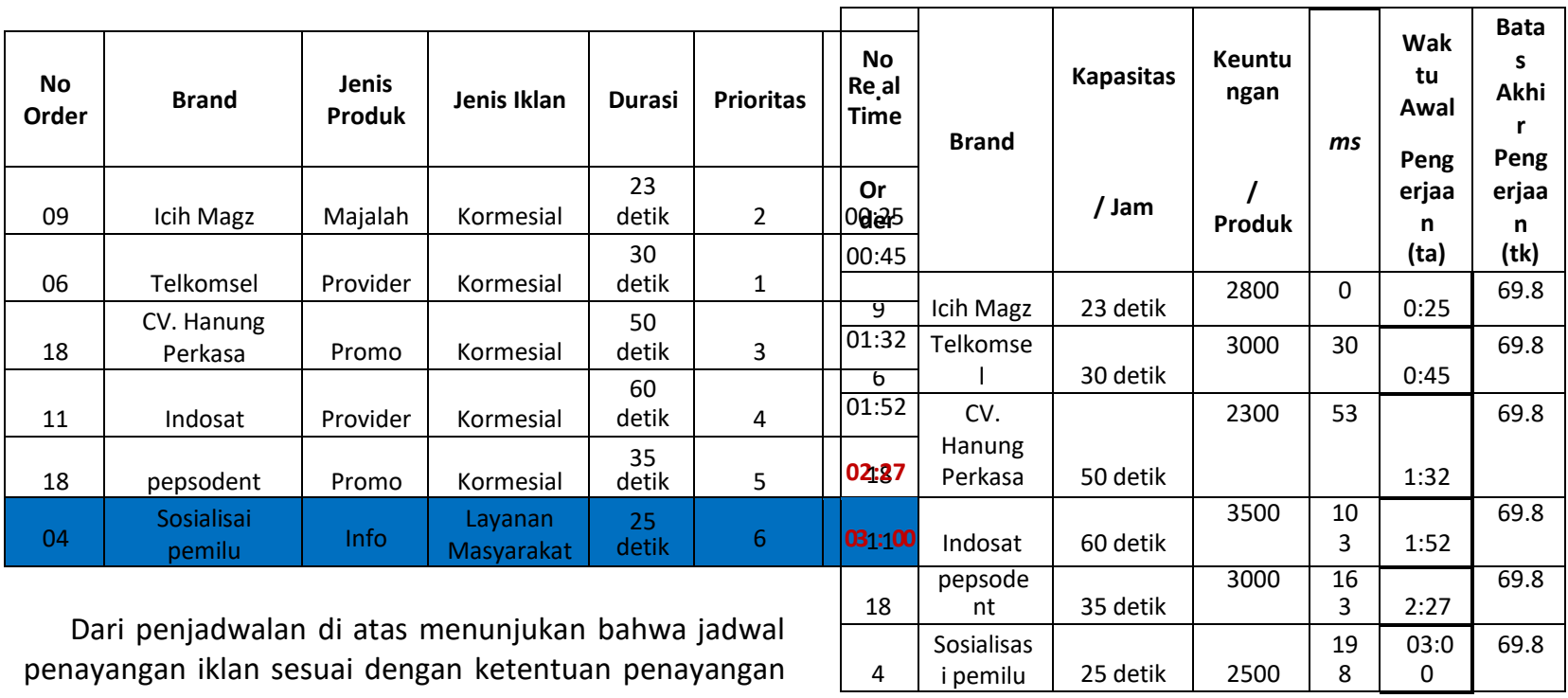

komersial dan waktu penayangan sesuai dengan durasi penayangan iklan. Maka dapat disimpulkan bahwa penjadwalan penayangan iklan tersebut efektif.

Gantt chart :

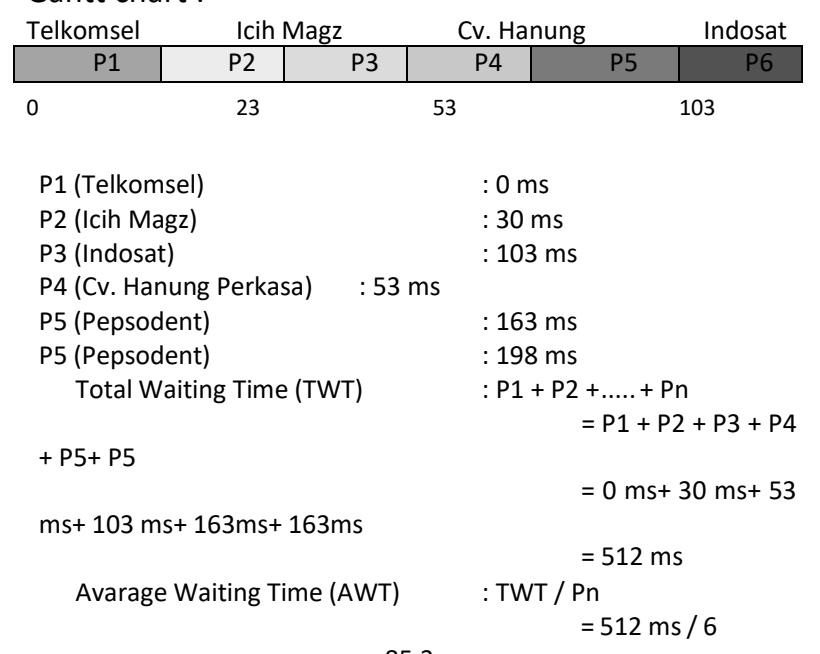

$$
=85.3 \mathrm{~ms}
$$

\section{Hasil}

Hasil pengukuran keuntungan potensial produksi penayangan iklan terhadap proses penjadwalan iklan yang sedang berjalan. Proses produksi penayangan iklan tersebut terdiri dari beberapa iklan yang masing-masing sedang berjalan di masing-masing lini iklan dan 1 pesanan iklan baru dengan nilai strategi marketing 69,8 .
Tabel diatas menunjukan parameter produk iklan yang sedang berjalan di proses produksi penyanagan iklan dan produk iklan baru yang merupakan produk iklan yang barifersedents. Sosial Pemilu

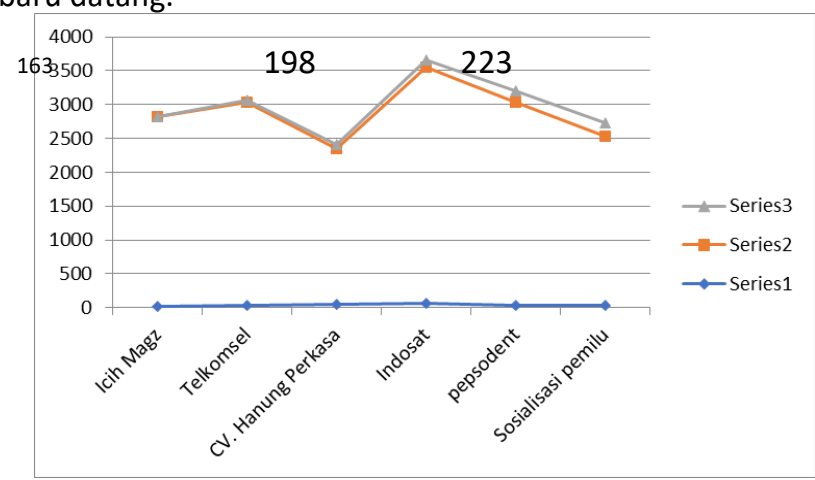

Gambar 3.1. Grafik Parameter Produksi Penayangan Iklan

\subsubsection{Pembahasan}

Untuk menguji kesesuaian aplikasi berdasarkan analisa dan perancangan, maka dilakukan pengujian fungsional dan non fungsional. Secara spesifik kriteria pengujian fungsional adalah sebagai berikut:

1. Mampu menampilkan dan mengelola data-data yang ada.

2. Perbandingan waktu antara sistem manual dengan sistem terkomputerisasi. 
Sedangkan secara spesifik kriteria pengujian non fungsional adalah sebagai berikut:

1. Kenyamanan antarmuka,

2. Mudah digunakan (user friendly)

Keunggulan dari algoritma penjadwalan berprioritas adalah biasanya memenuhi kebijaksanaan yang ingin mencapai maksimasi suatu kriteria diterapkan. Sebagai contoh, misalkan ada 6 proses yaitu P1, P2, P3, P4, P5,P6 dengan prioritas didasarkan atas besarnya waktu eksekusi dapat dilihat pada Tabel3.9.

Tabel Prioritas Awal

\begin{tabular}{|c|c|c|c|}
\hline Proses & Waktu Tiba & Lama Eksekusi & Prioritas \\
\hline P1 & 0 & 10 & 1 \\
\hline P2 & 0 & 1 & 4 \\
\hline P3 & 0 & 2 & 3 \\
\hline P4 & 0 & 1 & 5 \\
\hline P5 & 0 & 5 & 2 \\
\hline
\end{tabular}

\begin{tabular}{|c|c|c|c|c|c|}
\hline \multicolumn{5}{|l|}{ Gantt Chart } & \\
\hline P1 & P5 & P3 & P2 & P4 & \\
\hline 0 & 10 & 15 & 17 & 18 & 19 \\
\hline
\end{tabular}

Gambar 3.2. Gantt Chart Penjadwalan Proses

Disaat P1 dijalankan pada saat waktu eksekusi berjalan 4 detik datang P6 dengan lama eksekusi 4, maka proses penjadwalannya akan berubah menjadi :

Tabel Prioritas Brubah

\begin{tabular}{|c|c|c|c|}
\hline Proses & $\begin{array}{c}\text { Waktu } \\
\text { Tiba }\end{array}$ & $\begin{array}{c}\text { Lama } \\
\text { Eksekusi }\end{array}$ & Prioritas \\
\hline P1 & 0 & 10 & 1 \\
\hline P2 & 0 & 1 & 5 \\
\hline P3 & 0 & 2 & 4 \\
\hline P4 & 0 & 1 & 6 \\
\hline P5 & 0 & 5 & 2 \\
\hline P6 & 4 & 4 & 3 \\
\hline
\end{tabular}

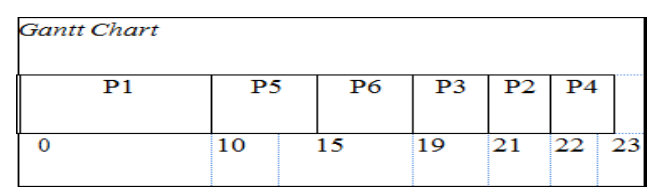

Gambar 3.3. Gantt Chart Penjadwalan Proses Setelah Prioritas Berubah

Iklan yang telah terdaftar untuk diputar dalam suatu acara akan mendapatkan prioritas untuk diproses. Prioritas ditempatkan pada iklan yang akan diproses berurutan berdasarkan besarnya biaya pemasangan iklan. Kemudian, iklan yang sudah mendapatkan prioritas akan diputar secara berurutan sesuai dengan prioritasnya. Prioritas dapat berganti pada saat proses dijalankan, karena proses penjadwalan iklan merupakan proses penjadwalandengan sifat yang dinamis.

Jika acara adalah suatu proses yang dianggap sebagai P1, kemudian iklan1, iklan2, iklan3, dan seterusnya digabungkan sebagai proses IK1, IK2, IK3 dengan nilai jumlah total durasi iklan tidak melebihi dari $20 \%$ durasi acara

Misalnya, diset bahwa interupsi iklan tiap jam adalah 4 kali, maka acara yang disiarkan lebih dari 1 jam, semisal 2 jam, jumlah interupsinya adalah 8 kali demikian seterusnya. Nilai 4 disini adalah nilai untuk contoh, jadi tidak harus menggunakan nilai 4 sebagai jumlah interupsi.

Sebagai contoh, apabila dalam suatu acara P1 yang berdurasi 60 menit, maka total durasi maksimal iklan per acara adalah $60 * 20 \%=12$ menit. Dan durasi acara sampai diinterupasi iklan adalah:

$$
\text { Durasi acara sampai diinterupsi }=\frac{60-12}{4}
$$

Maka akan didapat nilai untuk durasi acara sampai diinterupsi adalah 12. Jadi ketika proses acara P1 berjalan 12 menit akan diinterupsi oleh iklan. Iklan-iklan tersebut mempunyai durasi sendiri-sendiri (burst time) misal 30 detik atau 40 detik yang tergabung dalam proses IK yang mempunyai yang mempunyai durasi sama dengan durasi iklan per interupsi. Waktu proses IK akan diperoleh dari jumlah total durasi iklan dibagi interupsi.

I. ACARA 1 MELODI MEMORI 20.00-21.00

\begin{tabular}{|l|l|l|l|l|l|l|l|}
\hline P1 & IK1 & P1 & IK2 & P1 & IK3 & P1 & IK4 \\
\hline
\end{tabular}

Acara 2 Jazzy Tune $21.00-22.00$

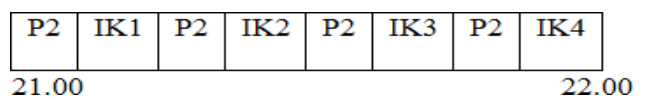

Tabel Daftar Iklan

\begin{tabular}{|c|c|c|c|c|}
\hline $\begin{array}{c}\text { No } \\
\text { Order }\end{array}$ & Brand & $\begin{array}{c}\text { Durasi } \\
\text { Detik }\end{array}$ & Frekuensi & $\begin{array}{c}\text { Total Durasi } \\
\text { (detik) }\end{array}$ \\
\hline 9 & Icih Magz & 30 & 4 & 120 \\
\hline 6 & Telkomsel & 23 & 2 & 46 \\
\hline 18 & CV. Hanung Perkasa & 60 & 4 & 240 \\
\hline 11 & Indosat & 50 & 3 & 150 \\
\hline
\end{tabular}

Karena biaya pemutaran iklan didasarkan atas lamanya iklan tersebut diputar, maka prioritas pemutaran iklan juga didapatkan atas total durasi pemutarannya. Maka, proritas akan didapatkan pada Tabel 3.12. 
Tabel Prioritas pada Iklan

\begin{tabular}{|c|c|c|c|}
\hline $\begin{array}{c}\text { No } \\
\text { Order }\end{array}$ & Brand & $\begin{array}{c}\text { Total Durasi } \\
\text { (detik) }\end{array}$ & Prioritas \\
\hline 9 & Icih Magz & 120 & 3 \\
\hline 6 & Telkomsel & 46 & 4 \\
\hline 18 & $\begin{array}{c}\text { CV. Hanung } \\
\text { Perkasa }\end{array}$ & 240 & 1 \\
\hline 11 & Indosat & 150 & 2 \\
\hline
\end{tabular}

Jumlah durasi iklan dalam suatu acara adalah $120+46$ $+240+150=556$ detik, atau sama dengan 9 menit 17 detik. Durasi acara Melodi Memori adalah 60 menit atau sama dengan 3600 detik. Durasi acara sampai interupsi adalah (3600 - 556) / $4=761$ detik atau sama dengan 12 menit 36 detik.

Durasi Putar iklan per interupsi $=556 / 4=139$ detik atau sama dengan 2 menit 18 detik.

Susunan Penyiaran acara dan iklan pada acara atau clock time acara Melodi Memori adalah :

$\begin{array}{lll}\text { 20:00:00+00:12:36=20:12:36 } & \text { Acara } & \text { P1 } \\ \text { 20:12:36+00:02:18=20:14:54 } & \text { Iklan } & \text { IK1 } \\ \text { 20:14:54+00:12:36=20:27:30 } & \text { Acara } & \text { P1 } \\ \text { 20:27:30+00:02:18=20:29:48 } & \text { Iklan } & \text { IK2 } \\ \text { 20:29:48+00:12:36=20:42:24 } & \text { Acara } & \text { P1 } \\ \text { 20:42:24+00:02:18=20:44:42 } & \text { Iklan } & \text { IK3 } \\ \text { 20:44:42+00:12:36=20:57:18 } & \text { Acara } & \text { P1 } \\ \text { 20:57:18+00:02:18=20:59:36 } & \text { Iklan } & \text { IK4 }\end{array}$

Proses produksi acara pertama-tama dilakukan oleh produser dengan menentukan acara untuk satu bulan ke depan. Produser membuat rundown acara bulanan dan disimpan ke dalam sistem. Untuk memproduksi acara secara lebih mendetil produser membuat rundown acara harian dan disimpan kedalam sistem. Data rundown harian tersebut akan diambil oleh music director untuk membuat clock time acara atau disebut sebagai skenario siaran. Data yang juga diperlukan oleh music director untuk membuat skenario siaran adalah data penyiaran order iklan.

\section{Kesimpulan}

Kesimpulan yang didapat dari penggunaan metode priority scheduling dalam sistem penjadwalan iklan pada radio Kiss FM untuk efesiensi produksi siaran adalah:

1. Sistem penjadwalan iklan terintegrasi merupakan sistem yang dapat membantu pengelolaan siaran iklan pada radio Kiss FM sehingga dalam pencatatan order iklan dan penjadwalan iklan tersebut.

2. Dalam sistem ini, penyiar dapat menayangkan iklan yang sudah dijadalkan tanpa harus mencari file iklan didalam komputer, sehingga iklan dapat ditayangkan sesuai jadwalnya.

3. Sistem dapat mencetak laporan bukti siar yang telah ditayangkan, sehingga akan meningkatkan efektifitas dan efesiensi dalam membuat laporan bukti siar.

\section{References}

[1] Hariyanto, Bambang, "Sistem Operasi", Bandung:Informatika, 1997

[2] William Stallings(2012). Operating Systems 7th Edition. Prentice Hall. New Jersey halaman 395 - 426.

[3] Avi Silberschatz, Peter Galvin, dan Grag Gagne (2013). Operating Systems CONCEPTS ninth Edition. John Wiley \& Sons. USA Halaman 261 - 312

[4] S.P. Hariningsih, S.T., Sistem operasi/ Edisi pertama Yogyakarta; penerbit graham ilmu 2003 (Bab III Hal 54)

[5] http://www.halcyon.com/pub/journals/21ps03vidmar 